\title{
Sustainable development of municipalities: financial assurance infrastructure
}

\author{
Galina Morunova ${ }^{1}$, Svetlana Gorbushina ${ }^{2}$, Vladimir Okrepilov $^{3}$, Svetlana Kuzmina,** \\ ${ }^{1}$ St. Petersburg State Economic University, 21, Sadovaya st., St. Petersburg, Russia \\ ${ }^{2}$ St. Petersburg State University, 7-9, Universitetskaya Emb., St. Petersburg, Russia \\ ${ }^{3}$ Institute of Regional Economic Problems of the Russian Academy of Sciences, St. Petersburg, \\ Russia \\ ${ }^{4}$ St.-Petersburg State Institute of Film and Television, 13, Pravda st., St.-Petersburg, Russia
}

\begin{abstract}
In the conditions of modern challenges, the issues of infrastructure support for the sustainable development of territories of all levels and, above all, their primary basis - municipal formations, acquire special significance. The research is based on the hypothesis of the relationship between the quality of infrastructure provision of municipalities, including their budgetary and managerial potential, and the sustainable social and economic development of the territory. Accordingly, the authors consider models of interaction between all subjects of economic and social ties of territorial formation, their innovative component and the nature of inclusion in the ensuring of sustainable development of municipalities. The recommendations on the formation of the financial security infrastructure with a view to ensure sustainable development of municipalities are also presented.
\end{abstract}

\section{Introduction}

Traditionally, the model of sustainable development has been focused primarily on the level of the country as a whole or its regions, to a lesser extent extending to the municipal level. Although, as practice shows, at the municipal level, through the formation of financial and budgetary sustainability, the basic conditions for the country's sustainable development as a whole are formed and are being implemented. In the research, the authors carried out a comprehensive assessment of the development of the municipalities of the Leningrad region and presented a methodology for their ranking on the socio-economic, budgetary and managerial potential of the territory, which allowed assessing the relationship between the quality of the institutional subsystem and the sustainable social and economic development of municipalities. The research is based on the materials of state statistical reporting and methods of statistical information processing, factor analysis, integrated rating assessment, mathematical modeling.

${ }^{*}$ Corresponding author: dolgache@mail.ru 


\section{The concept of sustainable development and its institutional support}

The crisis of the neo-liberal economic model, dominant in the 1970s and 1980s, the modern challenges of the global economy necessitated the search for a new model of a social system oriented toward sustainable, harmonious development. The concept of sustainable development was formed in conditions of the objective necessity of preserving the unity of the economic, social and natural systems, as the basis for the harmonious and stable development of society. Due to the global nature, these problems have become the subject of discussion by the international community with a view to develop a systematic approach to their solution. It is clarified that for the first time sustainable development issues were discussed at the United Nations Conference on the Environment in Stockholm on 16 June 1972. [1,2]. As a single system, the Sustainable Development Goals (SDGs) were presented in the Global Strategic Program "Transforming our world: the 2030 Agenda for Sustainable Development", approved by the UN on September 25, $2015[3,4]$. In essence, this is a set of benchmarks for future international cooperation in the field of global and national development for the period until 2030, the main idea of which is to ensure the quality of life in all its manifestations.

A special place in ensuring sustainable development, according to the development of international financial organizations, is assigned to supranational and national development institutions. (For more details, see S.Gorbushina [22]. In the world practice, development institutions are represented by various investment and credit organizations: financial corporations; funds, agencies, development banks, etc. As of today in the world there are about 750 development institutions, mostly banks. [6]. Their purpose is to finance programs and projects of international and national order that are of great social and economic importance, but which cannot be carried out by private business because of their scale or the absence of a clear economic effect. Accordingly, such structures are established, as a rule, by international organizations, associations of states or individual states and act to implement the strategic interests of the founders.

Development banks are, as a rule, multilateral banks, and often banking groups, with sufficiently diversified activities. By the area of activities there are international, regional and national banks of development. In the context of the concept of sustainable development of the United Nations, the leading structure is the World Bank as the main institution engaged in the development and implementation of basic strategies for world development. Russian development institutions are also quite multifaceted in terms of scope and status. At the federal level, there are State corporation "Bank for Development and Foreign Economic Affairs (Vnesheconombank)"; State corporation "Russian Corporation of Nanotechnologies"; investment fund of the Russian Federation; OAO Russian Venture Company; JSC "Agency for Housing Mortgage Lending"; State Corporation "Fund for Assistance to Housing and Communal Services Reform"; OJSC "Russian Agricultural Bank"; OJSC "Rosagroleasing"; OJSC Russian Foundation for Information and Communication Technologies; Foundation for Assistance to Small Innovative Enterprises in Science and Technology [7]. At the regional and municipal levels, they also establish their development institutions, which are included in the process of ensuring the sustainable development of the respective territories. It should also be noted a number of modern theories built on the initiative and practical participation of the municipalities themselves in ensuring sustainable harmonious development (Florida R.(2008), Lorenz, P. \& Moutchnik, A.(2016)) [8]. First of all, we are talking about the theory of "creative economy", which is based on intellectual activity, new technologies of interaction between all subjects of economic and social ties, generation and practical implementation of new knowledge. Within the framework of the "creative economy" new 
economic models of participation, new types of social relations are formed. At the same time, the authorities are responsible for the development of the legal framework, the territorial development strategy, coordination activities.

The researches of economists and financiers of various countries are devoted to the search for modern mechanisms of "creative economy", "participation economy", and ensuring sustainable development of the territories. Accordingly, as relevant, we can emphasize such issues as: support of local entrepreneurship in times of crisis (Balomenou Chrysanthi, Maliari Marianthi 2015 [9]); support of agricultural producers (Ignacio de los Ríos-Carmenado 2014 [10]); sustainable development of the territory as a result of supporting entrepreneurial initiatives (Ionela Gavrila-Paven 2014 [11]); the role of educational institutions in sustainable development (M. John Plodinec 2014 12]); construction of a regional development strategy (Daniela Antonescu 2014 [13]); development of national credit cooperation (Tarcisio Pedro Da Silva 2017[14]), credit cooperation in the field of energy technologies (Sarah M. Jordaan, Elizabeth Romo-Rabago 2017 [15]); interaction of regional and local authorities in creating conditions for sustainable development of the territory (Elena Sibirskaya 2015 [16]) and etc. Analyzing the perspectives and models for the development of the national and subnational level, Russian economists note the need for further transformation of the Russian economy (N.Sabitova, N.Ivanova [1,3]), building a model for managing the economic system based on selforganization and horizontal interaction of market subjects as the basis of development (A.Gershanok, E.Malyshev [5]).

The generalization of these researches and the analysis of modern models of building a municipal economy make it possible to conclude that for the sustainable development of the territory creative activity and social responsibility of all economic entities located on a particular territory is necessary, with the organizing and coordinating role of local and regional authorities, the so-called "participation economy". The subjects of social creative cooperation can be various creative associations, trade unions, associations, foundations, mutual aid societies, etc.

\section{Comprehensive evaluation of sustainable development of municipalities of the Leningrad region}

To identify the factors of the organization of municipal finance for the sustainable development of municipalities, it is logically sound to use already available information, such as:

$>$ assessment of socio-economic development;

$>$ assessment of the effective strength of local government (satisfaction of the population with the activities of local government);

$>$ data of budget implementation (budget and financial sustainability).

So the model of sustainable development of a municipal formation should be based on the following main components (potential): socio-economic development, budgetary and financial sustainability and effective activity of local government (managerial potential), which results are in people's satisfaction with the activities of local governments. The advantage of this approach is that it does not require additional information gathering. The model was tested on the example of the Leningrad region as the most typical subject of the Russian Federation. In carrying out a comprehensive assessment of the development potential of the municipalities of the Leningrad Region for 2014 (G. Morunova [18]), a final rating of sustainable development of municipalities was drawn up, with the distribution of socio-economic potential, budgetary potential and level of citizens' satisfaction with the activities of local government (managerial potential) (Table 1), which gave rise to rather contradictory conclusions 
Table 1. Rating of municipalities of the Leningrad Region on the potential of sustainable development [5].

\begin{tabular}{|c|c|c|c|c|}
\hline \multirow[b]{2}{*}{ 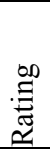 } & & \multicolumn{3}{|c|}{$\begin{array}{l}\text { The amount of seats in the components } \\
\text { of the rating by: }\end{array}$} \\
\hline & & $\begin{array}{c}\text { Socio-economic } \\
\text { potential }\end{array}$ & $\begin{array}{c}\text { Managerial } \\
\text { potential }\end{array}$ & $\begin{array}{c}\text { Budgetary } \\
\text { potential }\end{array}$ \\
\hline 1. & Vsevolozhsky municipal district & 1 & 15 & 1 \\
\hline 2. & Tosnensky municipal district & 4 & 10 & 4 \\
\hline 3. & Kirishsky municipal district & 12 & 2 & 5 \\
\hline 4. & Sosnovoborsky city district & 15 & 1 & 8 \\
\hline 5. & Slantsevsky municipal district & 5 & 4 & 15 \\
\hline 6. & Volosovsky municipal district & 9 & 3 & 12 \\
\hline 7. & Kingiseppsky municipal district & 6 & 9 & 9 \\
\hline 8. & Luzhsky municipal district & 10 & 8 & 7 \\
\hline 9. & Kirovsky municipal district & 13 & 7 & 6 \\
\hline 10. & Gatchinsky municipal district & 11 & 14 & 2 \\
\hline 11. & Lodeinopolskiy municipal district & 7 & 6 & 14 \\
\hline 12. & Boksitogorskiy municipal district & 2 & 13 & 16 \\
\hline 13. & Podporozhsky municipal district & 3 & 12 & 17 \\
\hline 14. & Lomonosovsky municipal district & 18 & 5 & 11 \\
\hline 15. & Volkhovsky municipal district & 8 & 17 & 10 \\
\hline 16. & Vyborgsky municipal district & 17 & 16 & 3 \\
\hline 17. & Priozersky municipal district & 16 & 11 & 13 \\
\hline 18. & Tikhvinsky municipal district & 14 & 18 & 18 \\
\hline
\end{tabular}

The task in forming a comprehensive rating of sustainable development of municipalities is to identify points of contact with the budget component (financial stability) and municipalities that fall into the risk zone. The indicators of the sustainable development of the municipalities of the Leningrad Region in 2014, with the distribution according to socio-economic, budgetary and managerial potentials, are shown in Fig. 1.

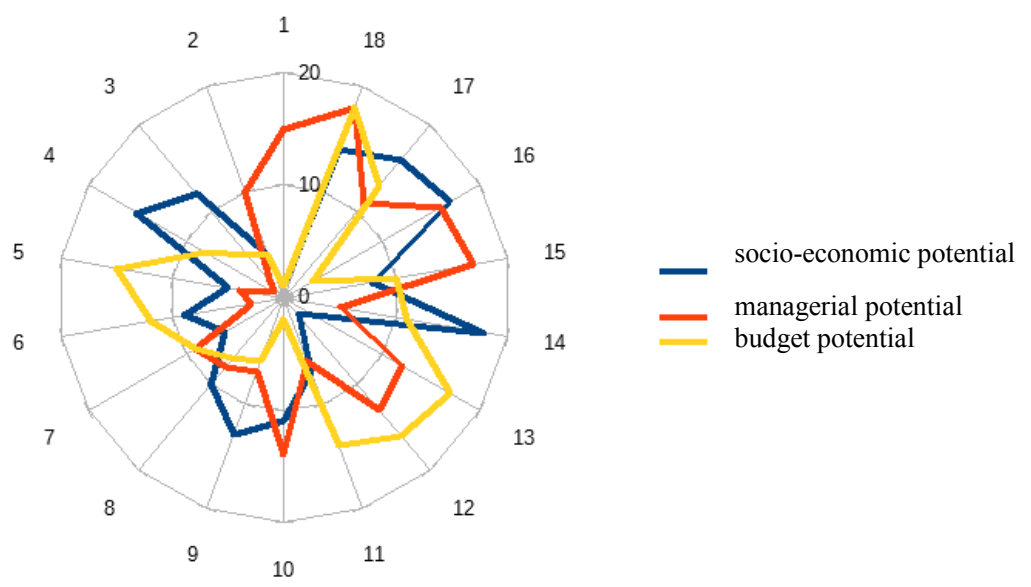

Fig. 1. Comprehensive assessment of sustainable development of municipalities in terms of development potential.

It can be seen from the diagram that the indicators under consideration have multidirectional dynamics. So, there are areas that have low budget potential, low level of 
social and economic development, but the population's satisfaction with the activity of the municipal entity (managerial potential) is at a sufficiently high level. For example, Sosnovoborskiy city district in 2014 occupied the 4th place in the rating of integrated sustainability, in 2016 - the 12th, while the budget potential in the rating of 2014 - the 8th place, in 2016 - the 17th , but for managerial potential, all considered years, it remains on the 1-st place, it should be noted that it is in this district developed participatory budgeting.

In the first lines of the rating on sustainable development we can see municipalities with high socio-economic potential, managerial potential, but the budget potential rating is at the level of 15 or even 17 places. From which follows the conclusion that the budget potential doesn't have a direct impact on the socio-economic indicators, the population's satisfaction with the management of the municipal entity and, ultimately, on the sustainable development of the territory.

The construction of the sustainable development rating of municipalities for selected components allows us to conclude that the increase in the volume of budget financing doesn't entail: 1) improving the socio-economic status of the municipal formation; 2) increase of citizens' satisfaction with the activity of the municipal entity (managerial potential).

It should be noted that along with the budgets there is a special source of sustainable development of municipalities - self-management and self-financing, strictly subordinate to the strategy developed. They are based on financial institutions of state and municipal development, the potential of financial organizations located in the corresponding territory, business structures of the real sector, the population.

In the sphere of municipal economic policy the main vector is traditionally the attraction of investments, the use of mechanisms of municipal-private partnership, the development and support of small and medium-sized businesses, the formation of a strategic management system. The practices of some municipalities are aimed at developing cooperation in the territory of a municipal formation and clustering the branches of the economy as a way of supporting small and medium-sized businesses.

The financial institutions for the sustainable development of municipalities include the Regional Funds for Support of Local Initiatives, from which the winning municipalities, on the basis of evaluating their bids, are awarded grants in the nomination "Municipal Economic Policy and Municipal Finance Management" in the form of intergovernmental transfers[18].

A special place in the system of stimulating development is occupied by Programs for supporting local initiatives [19]. This project has been implemented in Russia by the World Bank for more than 10 years. In essence, this is practical involvement of citizens in local self-government, solving problems of local level by joint forces of the population, business and authorities. Over this time, more than 4,000 projects have been implemented, related to the improvement and development of the territory, more than 150 thousand people annually participate in the Project throughout the country. The beneficiaries are the population of specific municipalities. In 2016 the Ministry of Finance of the Russian Federation jointly with the World Bank launched the project "Development of participatory budgeting in the constituent entities of the Russian Federation in 2016-2018." At the same time, for the financing of the programs, the fixed assets are allocated from the budget of the constituent entity, partly from the local budget, and the citizens' funds are also raised, a kind of collective financing. In our opinion, this mechanism should be developed by involving other financial institutions in cooperation. In this case, it is advisable to provide tax preferences for economic entities of the territory - the winners of the competition, which will make it possible to intensify their activities.

As the world practice shows, one of the promising areas of collective financing for sustainable development of the territory is credit cooperation. At the same time, according 
to the estimates of the Central Bank of Russia, the share of credit cooperatives in the financial system of the country is extremely low. Credit cooperatives in Russia unite only about $1.1 \%$ of the adult population of the country, while about $75 \%$ of the adult population have accounts with credit institutions; the aggregate assets of credit cooperatives make up less than $0.12 \%$ of the assets of credit institutions; the aggregate savings of citizens placed in credit cooperatives make up less than $0.25 \%$ of the volume of deposits of citizens placed with credit institutions [20,17]. By the way, according to The Economist (2015), the credit cooperatives sector in various countries is quite significant: the number of shareholders of credit cooperatives around the world doubled from 2000 to 2015, the total volume of assets grew by $130 \%$ in real terms. At the same time, credit cooperatives are common not only in developing but also in developed countries: today 39\% of adult Americans belong to any credit cooperative, in Australia members of such financial organizations are $24 \%$ of the population $[21,22]$.

As non-financial institutions of sustainable development, higher education institutions are increasingly active as centers for the pooling of advanced science, governance and business (the experience of the Netherlands in the 1990s). In particular, using the enormous scientific, methodological, creative potential, higher educational institutions should become centers for the development of strategies for the development of municipalities, reforming their financial and budgetary system $[23,24]$.

\section{Conclusions}

Thus, sustainable development of municipalities can become a new paradigm for the development of the whole country. The study of modern models of the transformational economy of the national and territorial levels allows us to justify the concept of building a sustainable development model at the municipal level, based on the ideas of the creative economy, the participation economy.

The proposed method of integrated assessment of sustainable development of municipalities, based on the system of aggregated indicators of budget sustainability, social and economic development, the effectiveness of local government, let use from a new angle the accountability of local government, quantify the potential of the municipal formation, justify the development strategy of municipalities and the region, the most built on selfmanagement and self-financing.

\section{References}

1. N. Ivanova, I. Katsyuba, G. Guseinova, Management of public finances: burning issues, new solutions and development strategies, collective monograph (St. Petersburg State Economic University, St. Petersburg, 2016)

2. Resolution of the UN General Assembly No. 2997 of December 15 (1972) (A/RES/2997(XXVII)) https://www.unenvironment.org/

3. N. Sabitova, M. Shagiahmetov, N. Ivanova, International Journal of Economics and Financial Issues 6-8, 288 - 292 (2017)

4. URL : https://sustainabledevelopment.un.org/content/documents/6754Technical $\% 20$ report $\% 20$ of $\% 20$ the $\% 20$ UNSC $\% 20$ Bureau $\% 20 \% 28$ final $\% 29$.pdf

5. A. Gershanok, E. Malyshev,Journal of Creative Economy 12-5, 587-606 (2018) doi: 10.18334 / ce. 12.5 .39104

6. URL : http://www.veb.ru/common/upload/files/veb/mag/mag-web-5.pdf

7. URL : http://economy.gov.ru/minec/activity/sections/instdev/institute 
8. R. Florida, Who's Your City? How the Creative Economy Is Making Where to Live the Most Important Decision of Your Life (Basic Books, 2008) ISBN 0465003524

9. P. Lorenz, A. Moutchnik, Corporate Social Responsibility in the UK Creative Industries, Building the Missing Link., UWF (2016) doi:10.1007/s00550-016-0405-8

10. B. Chrysanthi, M. Marianthi, Procedia Economics and Finance 33, 535-551 (2015) ISSN 2212-5671

11. I. de los Ríos-Carmenado, A. Turek Rahoveanu, A. Afonso Gallegos, Procedia Economics and Finance 8, 614-621 (2014) ISSN 2212-5671

12. I. Gavrila-Paven, E.M. Dobrescu, E.-M. Dobre, Procedia Economics and Finance 15, 1065-1070 (2014) ISSN 2212-5671

13. M.J. Plodinec, W.C. Edwards, R.K. White, Procedia Economics and Finance 18, 9-16 (2014) ISSN 2212-5671

14. D. Antonescu, Procedia Economics and Finance 15, 1091-1097 (2014) ISSN 22125671

15. T. Pedro Da Silva, M. Leite, J. Carla Guse, V. Gollo, Contaduría y Administración 625, 1442-1459 (2017)

16. S.M. Jordaan, E. Romo-Rabago, R. McLeary, L. Reidy, I. M. Herremans, Renewable and Sustainable Energy Reviews 78, 1397-1409 (2017)

17. E. Sibirskaya, O. Stroeva, E. Simonova, Procedia Economics and Finance 27, 507-515 (2015)

18. G. Morunova, Theory, legislation and practice of the organization of municipal finance in the transformational economy (St. Petersburg State Economic University, St. Petersburg, 2016)

19. Order of the Ministry of Economic Development of Russia from December 9, 2016 No. 798

20. I. Shulga, A. Sukhova, Program to support local initiatives: improving local government (Alex, Moscow, 2016)

21. URL : http://www.cbr.ru/analytics/ppc/consultation_paper_171003_01.pdf

22. URL : http://www.economist.com/news/finance-and-economics/21677218-venerableform-banking-comes-back-fashion-winning-converts/translation:

http://www.vestifinance.ru/articles/64212

23. S. Gorbushina, I. Maiburov, Y. Ivanov, Ecological taxation. Theory and world trends (UNITY-DANA, Moscow, 2018)

24. L. Svatovskaya, A. Sychova, M. Sychov, V. Okrepilov, MATEC Web of Conferences 53, 01024 (2016)

25. G. Morunova, S. Kuzmina, T. Sorvina, MATEC Web of Conferences 193, 05058 (2018) https://www.matec-conferences.org/articles/matecconf/pdf/2018/52/mateccon fesci201805058.pdf 